\title{
The Relationship Between Job Uncertainty and Job Satisfaction: The Moderating Effect of Charismatic Leadership, Organizational Communication, and Self-Efficacy
}

\author{
Wanye Cheng ${ }^{1} \&$ Sang Woo Hahm ${ }^{1}$ \\ ${ }^{1}$ Department of Business Administration, Soongsil University, Seoul, South Korea \\ Correspondence: Sang Woo Hahm, School of Business Administration, Soongsil University, Seoul, South Korea.
}

Received: April 30, 2019

Accepted: May 30, 2019

Online Published: June 11, 2019

doi:10.5430/ijfr.v10n5p338

URL: https://doi.org/10.5430/ijfr.v10n5p338

\begin{abstract}
With the arrival of the fourth industrial revolution, many things are changing rapidly, including the way that people work. These changes to the work environment can make workers feel uncertain about their jobs, which in turn can lead to anxiety and complaints about the job, amongst other negative variables. This study explains the factors that can reduce the negative influence of job uncertainty at the organizational, leader-ship, and worker levels. Job uncertainty involves a variety of changes and new directions driven by new technologies and information. Leaders possessed of a charismatic leadership style who are better able to enunciate a clear vision in such dynamic situations, the provision of a variety of useful information related to change within an organization, and workers' self-efficacy in relation to change will all reduce the effects of job uncertainty. In today's job environment, a degree of uncertainty is almost unavoidable. Therefore, by reducing the negative impact of this uncertainty, workers can be more satisfied with their jobs and will be able to achieve higher levels of performance.
\end{abstract}

Keywords: job uncertainty, job satisfaction, charismatic leadership, organizational communication, self-efficacy

\section{Introduction}

Today's job environment is changing rapidly (Armenakis, \& Bedeian, 1999). The Fourth Indus-trial Revolution was discussed at length at the World Economic Forum in 2016. The characteristics of the Fourth Industrial Revolution include the effects of the previous Industrial Revolution and the introduction of new and advanced technologies (Osuji, et.al. 2017; Park, 2018). People will face a new age of widespread and rapid changes. Job uncertainty (JU) will also increase along with these changes. Uncertainty is essentially unpredictability about the future (Aspers, 2018). Job uncertainty has a negative effect on the members of an organization and job satisfaction (JS) and can lead to an overall worsening of job performance (Bastien, 1987; Johnson, Bernhagen, Miller, \& Allen, 1996). Generally, uncertainty is considered to be negative, and because it is driven by an external factor, that is environmental and societal changes, it is difficult to actually decrease levels of uncertainty itself (Ruan, Hsee, \& Lu, 2018). Research into how to reduce the negative influence of uncertainty is needed. This study emphasizes the importance of reducing job uncertainty and suggests that corporations should strive to provide as much stability as possible to their members in an uncertain environment. It also explains the negative effect of job uncertainty on job satisfaction. It emphasizes the importance of charismatic leadership (CL), organizational communication (OC), and self - efficacy (SE) as measures to reduce this negative influence. The negative impact of uncertainty on job satisfaction can be reduced through better communication at the organizational level, leadership at the relationship level, and self - efficacy at the individual level (Paulsen, Callan, Grice, Rooney, Gallois, Jones, Jimmieson, \&Bordia, 2005; Bandura, 1977). Resultantly, this paper explains what kinds of efforts are needed at leadership, organizational and individual levels when uncertainty increases in rapidly changing environments.

\section{Literature Review}

\subsection{Job Uncertainty}

JU essentially involves uncertainty about job changes, role changes, and promotion opportunities (Hirst, 1981). JU is largely composed of job volatility (which indicates how much work is done in exceptional cases) and job complexity (which indicates how complex the job is) (Bordia, Hobman, Jones, Gallois, \& Callan, 2004). 
JU refers to job volatility in the work environment, and the difficulty or complexity of the job. The uncertainties associated with the job include all direct and indirect interactions to achieve the organization's goals (Dess \& Beard, 1984; Kamau, Mwania \& Njue 2018).

The volatility and complexity of a job lead to job uncertainty, and the greater the ambiguity and complexity of a job the greater will be the level of job uncertainty (Umanath \& Kim, 1992). Job complexity also refers to how many problems must be solved in the performance of a job (van de Ven, Delbecq, \& Koenig, 1976; Saad Umer \& Ahmed 2018). If a job involves many tasks, problem solving may require the assimilation of a large amount of complex information. Uncertainty can be said to be a crucial variable in a rapidly changing work environment.

\subsection{Job Satisfaction and Job Uncertainty}

Job satisfaction (JS) is an important personal attitude related to work (Pfeffer, 1994). JS is defined as the degree of joy or positive emotional state which is determined by an individual's evaluation of their job (Hoppock, 1935). JS is a harmony of psychological, physiological, and environmental circumstances. Those workers with high levels of job satisfaction will say they are satisfied with their job (Umrani, Mahmood \& Ahmed, 2016; Smith, 1955; Lari, NYangweso \& Rono 2017).

In an uncertain environment, workers often do not know how to approach their new work. They need to be perceptive and adaptable in an uncertain situation, need to learn new things and skills, and may even no longer have the opportunity to use existing skills that they are competent with (Park \& Jung, 2017; Dunst,et.al 2018). Uncertainty in the organization has an important effect on levels of individual job satisfaction, stress, turn-over and behavior (Jermsittiparsert, 2016; Locke, 1976). Therefore, JU may have a negative impact on job performance and JS.

\subsection{Charismatic Leadership and Job Uncertainty}

Charisma has been called "God's grace", and said to involve the ability to foretell the future or to perform miracles (Weber, 1947). This paper focuses on the effects of CL on members' values, emotions, levels of unconscious motivation and self-esteem (Waldman, Ramirez, House, \& Puranam, 2001; Ng, 2018). CL involves a strong desire for power, self-confidence, and a strong belief in one's faith and ideals. A strong desire for power motivates leaders to influence members. Confidence and strong beliefs increase members' confidence when judging leaders. Leaders with confidence and strong beliefs increase members' levels of trust in them.

Leaders with charismatic leadership provide necessary information, motivate members and reduce levels of tension and uncertainty about new environments. They provide organizational goals and visions and influence members to follow. Thus, uncertainty about a new job environment can be reduced, and members can feel greater self-worth and confidence, and improve their job performance (Ali \& Haseeb, 2019; Agle, Nagarajan, Sonnenfeld, \& Srinivasan, 2006).

\subsection{Organizational Communication and Job Uncertainty}

Communication refers to the general exchange of information and opinions. OC is a process of exchanging information between an organization and its members (Go, Go, Gwon, Kim, Kim, \& Kim, 2014). The purpose of OC is to inform members about the organization's important information. OC achieves organizational goals through interactions among organization members (Baron \& Kenny, 1986). Existing research has demonstrated that OC enhances organizational goals and development by enhancing members' JS (Price, 1997; Abdulkarim,et.al 2017; Dierker, et.al 2018).

Members can help to get the information they need to fully understand a situation through OC in an uncertain environment. Members can make better judgments about the situation and improve their job performance (Jiang \& Probst, 2014). Information is a valuable resource. As OC improves, members can get information in real time and share it amongst themselves. With this information, they can better predict the business environment, and it is possible to increase the sense of control over new environmental changes that members feel (Frahn \& Brown, 2007).

\section{Method}

This study sent 92 questionnaires in person or by email to workers in Korea. A demographic analysis of the respondents is as follows: Of the total participants $50(54.3 \%)$ were male and $42(45.7 \%)$ were female. $59(64.1 \%)$ of the participants were aged between 20 to 29 years old, 30 (32.6\%) of the participants were aged between 30 to 39 years old, 2 (2.2\%) of the participants were aged between 40 to 49 years old, and $2(2.2 \%)$ of the participants were over 50 years old. $39(42.4 \%)$ of the participants had worked for between 1-2 years at their current workplace, 34 (37.0\%) participants had worked for between 2-3 years at their current workplace, $9(9.8 \%)$ had worked between 3-4 
years at their current workplace, 5 (5.4\%) had worked between 4-5 years at their current workplace, and 5 (5.4\%) had worked for over 5 years at their current workplace.

Next we used five items to measure JU (Paulsen, Callan, Grice, Rooney, Gallois, Jones, Jimmieson, \& Bordia, 2005). A sample item includes "The level of influence you will have over changes in your job ". JS was measured by 4 items (Mossholder, Settoon, \& Henagan, 2005). A sample item includes "All in all, I am satisfied with my job". To measure CL, we used 8 items (Bass \& Avolio, 1995). A sample item includes "My leader tries to talk about his values and beliefs". OC was measured by 8 items (Jiang \& Probst, 2014), and a sample item includes "When plans at work change unexpectedly, my supervisor tells me why." Finally, SE was measured by 8 items (Chen, Gully, \& Eden, 2001; Dolgopolova, Hye \& Stewart 2014). A sample item includes "I will be able to achieve most of the goals that I have set for myself". All items were measured by a 7-point Likert-type scale.

\section{Analysis}

The results of the exploratory factor analysis for this research are shown below in [Table 1]. Table I displays the results of Cronbach's Alpha for reliability and correlation analysis. An alpha of .70 is a good cut off value, and is acceptable (Santos, 1999). For our research all values of Cronbach's Alpha are above .70 (JU=.946, JS=.957, $\mathrm{CL}=.932, \mathrm{OC}=.971, \mathrm{SE}=.959)$. The results show that the reliability of this research is acceptable.

Table 1. Exploratory factor analysis

\begin{tabular}{lllllll}
\hline & \multicolumn{2}{l}{ Component } & & & \multicolumn{2}{l}{ Cronbach's } \\
\cline { 2 - 7 } KMO=.913 & 1 & 2 & 3 & 4 & \multicolumn{2}{l}{ Alpha } \\
\hline JU1 & -.143 & -.131 & -.037 & .862 & -.182 & \\
\hline JU2 & .026 & -.098 & -.009 & .855 & -.123 & \\
\hline JU3 & -.027 & -.110 & -.109 & .917 & -.098 & .946 \\
\hline JU4 & -.130 & .003 & -.177 & .895 & -.045 & \\
\hline JU5 & -.067 & -.039 & -.041 & .921 & -.082 & \\
\hline JS1 & .306 & .252 & .311 & -.182 & .751 & \\
\hline JS2 & .274 & .311 & .310 & -.297 & .709 & \\
\hline JS3 & .291 & .321 & .226 & -.277 & .764 & .957 \\
\hline JS4 & .298 & .270 & .276 & -.237 & .789 & \\
\hline SE1 & .163 & .837 & .126 & -.146 & .092 & \\
\hline SE2 & .224 & .865 & .156 & -.076 & .024 & \\
\hline SE3 & .152 & .845 & .216 & -.093 & .116 & \\
\hline SE4 & .314 & .788 & .039 & -.038 & .126 & .959 \\
\hline SE5 & .202 & .843 & .144 & -.062 & .172 & \\
\hline SE6 & .193 & .818 & .139 & -.038 & .297 & \\
\hline SE7 & .192 & .794 & .275 & -.074 & .127 & \\
\hline SE8 & .283 & .818 & .155 & -.032 & .207 & \\
\hline CL1 & .233 & .256 & .630 & -.184 & .231 & \\
\hline CL2 & .390 & .198 & .696 & -.146 & .303 & \\
\hline CL3 & .424 & .195 & .760 & -.098 & .190 & \\
\hline CL4 & .209 & .068 & .477 & .093 & .456 & .932 \\
\hline CL5 & .474 & .138 & .702 & -.138 & .163 & \\
\hline CL6 & .608 & .125 & .630 & -.117 & .152 & \\
\hline CL7 & .316 & .319 & .715 & -.058 & .218 & \\
\hline CL8 & .439 & .321 & .645 & -.034 & .121 & \\
\hline OC1 & .819 & .281 & .290 & -.010 & .161 & \\
\hline OC2 & .815 & .247 & .243 & -.031 & .177 & \\
\hline OC3 & .813 & .278 & .265 & -.077 & .158 & \\
\hline & & & & & & \\
\hline
\end{tabular}




\begin{tabular}{lllllll}
\hline OC4 & .801 & .317 & .222 & -.071 & .183 & \\
\hline OC5 & .819 & .144 & .329 & -.087 & .208 & .971 \\
\hline OC6 & .807 & .223 & .298 & -.089 & .189 & \\
\hline OC7 & .839 & .213 & .321 & -.134 & .186 & \\
\hline OC8 & .799 & .289 & .177 & -.057 & .143 & \\
\hline Total & 7.396 & 6.742 & 4.692 & 4.427 & 3.303 & \\
\hline \% of Variance & 22.413 & 20.430 & 14.217 & 13.415 & 10.008 & \\
\hline Cumulative \% & 22.413 & 42.843 & 57.060 & 70.475 & 80.483 & \\
\hline
\end{tabular}

Next, correlation analysis was conducted (see Table 2). The results of the correlation analysis showed that JU was negatively related to JS ( $r=-.421)$, SE ( $r=-.209)$, CL $(r=-.254)$, and OC $(r=-.212)$. Furthermore, SE negatively related to $\mathrm{JU}(\mathrm{r}=-.209)$ and positively related to $\mathrm{JS}(r=.563)$. CL negatively related to JU( $r=-.254)$ and positively related to JS $(r=.699)$. OC negatively related to $\mathrm{JU}(r=-.212)$ and positively related to JS $(r=.617)$.

Table 2. Correlation analysis

\begin{tabular}{llllllll}
\hline & Mean & \multicolumn{2}{l}{ Std. Deviation JU } & JS & SE & CL & OC \\
\hline JU & 3.6152 & 1.55718 & - & & & & \\
\hline SS & 5.2582 & 1.39487 & $-.421^{* * *}$ & - & & & \\
\hline SE & 5.6073 & .93147 & $-.209^{*}$ & $.563^{* * *}$ & - & & \\
\hline CL & 5.0883 & .97223 & $-.254^{*}$ & $.699^{* * *}$ & $.536^{* * *}$ & - & \\
\hline OC & 5.1481 & 1.04893 & $-.212^{*}$ & $.617^{* * *}$ & $.560^{* * *}$ & $.775^{* * *}$ & - \\
\hline
\end{tabular}

$* * *: \mathrm{p}<.001, * *: \mathrm{p}<.01, *: \mathrm{p}<.05$.

Table 3 displays the moderating effect of SE between JU and JS. The results showed that SE does not moderate between JU and JS $(\beta=1.127$, sig=.06).

Table 3. The moderating effect of SE between JU and JS

\begin{tabular}{|c|c|c|c|c|c|c|c|}
\hline \multicolumn{8}{|l|}{ dependent: JS } \\
\hline & \multicolumn{2}{|l|}{ Step1 } & \multicolumn{2}{|l|}{ Step2 } & \multicolumn{3}{|l|}{ Step3 } \\
\hline & $\bar{\beta}$ & $\mathrm{t}$ & $\beta$ & $\mathrm{t}$ & $\beta$ & $\mathrm{t}$ & VIF \\
\hline $\mathrm{JU}$ & $-.421 * * *$ & -4.403 & $-.317 * * *$ & -3.821 & $-1.441 *$ & -2.424 & 1.118 \\
\hline SE & & & $.497 * * *$ & 5.989 & .067 & .277 & 1.053 \\
\hline $\begin{array}{l}\text { Moderate } \\
\text { (JU x SE) }\end{array}$ & & & & & 1.127 & 1.909 & 1.070 \\
\hline Adjusted $\mathrm{R}^{2}$ & $.177(.168)$ & & $.414(.400)$ & & $.437(.418)$ & & \\
\hline $\begin{array}{l}\Delta \text { Adjusted } \\
\mathrm{R}^{2}\end{array}$ & - & & $.237(.232)$ & & $.023(.018)$ & & \\
\hline $\mathrm{F}$ & $19.386 * * *$ & & $31.379 * * *$ & & $22.755 * * *$ & & \\
\hline
\end{tabular}

$* * *: \bar{p}<.001, * *: \mathrm{p}<.01, *: \mathrm{p}<.05$

Table 4 displays the moderating effect of CL between JU and JS. The results showed that CL positively moderated between JU and JS ( $\beta=1.186$, sig=.001). 
Table 4. The moderating effect of CL between JU and JS dependent: JS

\begin{tabular}{|c|c|c|c|c|c|c|c|}
\hline & Step1 & & Step2 & & Step3 & & \\
\hline & $\beta$ & $\mathrm{t}$ & $\beta$ & $\mathrm{t}$ & $\beta$ & $\mathrm{t}$ & VIF \\
\hline $\mathrm{JU}$ & $-.421 * * *$ & -4.403 & $-.262 * *$ & -3.547 & $-1.425 * * *$ & -4.210 & 1.095 \\
\hline $\mathrm{CL}$ & & & $.627 * * *$ & 8.476 & .052 & .318 & 1.177 \\
\hline $\begin{array}{l}\text { Moderate } \\
\text { (JU x CL) }\end{array}$ & & & & & $1.186 * *$ & 3.496 & 1.108 \\
\hline Adjusted $\mathrm{R}^{2}$ & $.177(.168)$ & & $.545(.534)$ & & $.600(.587)$ & & \\
\hline$\triangle$ Adjusted $\mathrm{R}^{2}$ & - & & $.368(.366)$ & & $.055(.053)$ & & \\
\hline $\mathrm{F}$ & $19.386 * * *$ & & $53.242 * * *$ & & $44.046 * * *$ & & \\
\hline
\end{tabular}

$* * *: \bar{p}<.001, * *: \mathrm{p}<.01, *: \mathrm{p}<.05$

Figure 1 also shows the moderating effect of CL. It shows that if CL is low when JU is high, JS is decreased. However, if CL is high, higher JU leads to a slightly higher JS. This demonstrates that CL positively moderates the relationship between JU and JS.

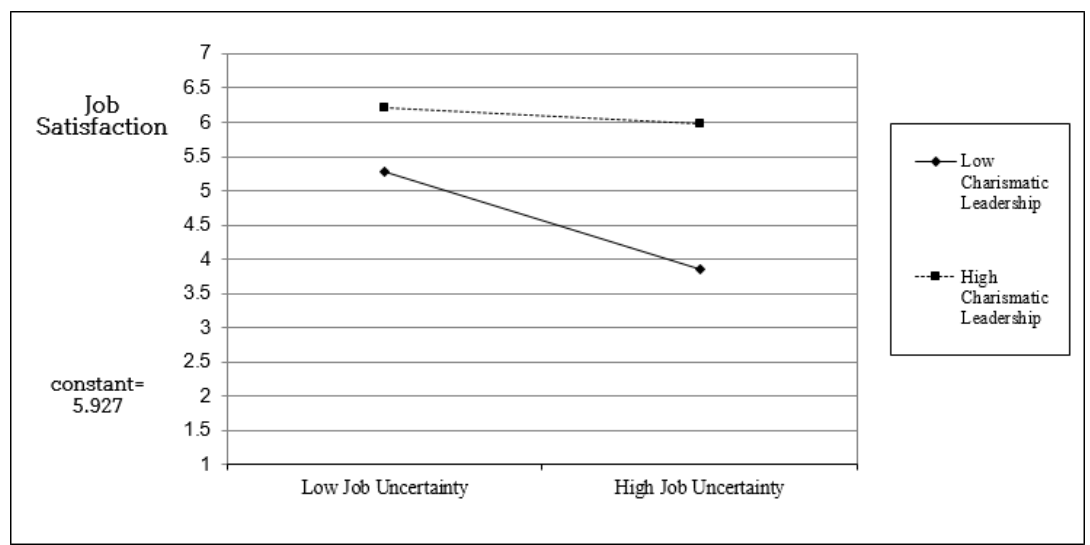

Figure 1. The moderating effect of CL

Table 5 displays the moderating effect of OC between JU and JS. The results showed that OC positively moderated between JU and JS ( $\beta=1.090$, sig=.004).

Table 5. The moderating effect of OC between JU and JS

\begin{tabular}{|c|c|c|c|c|c|c|c|}
\hline & \multicolumn{2}{|l|}{ Step1 } & \multicolumn{2}{|l|}{ Step2 } & \multicolumn{3}{|l|}{ Step3 } \\
\hline & $\beta$ & $\mathrm{t}$ & $\beta$ & $\mathrm{t}$ & $\beta$ & $\mathrm{t}$ & VIF \\
\hline $\mathrm{JU}$ & $-.421 * * *$ & -4.403 & $-.304 * * *$ & -3.842 & $-1.346 * * *$ & -3.702 & 1.078 \\
\hline OC & & & $.552 * * *$ & 6.988 & .009 & .044 & 1.147 \\
\hline
\end{tabular}




\begin{tabular}{|c|c|c|c|c|c|}
\hline $\begin{array}{l}\text { Moderate } \\
\text { (JU x OC) }\end{array}$ & & & $1.090 * *$ & 2.931 & 1.108 \\
\hline Adjusted $\mathrm{R}^{2}$ & $.177(.168)$ & $.469(.457)$ & $.516(.499)$ & & \\
\hline$\triangle$ Adjusted $\mathrm{R}^{2}$ & - & $.292(.289)$ & $.047(.042)$ & & \\
\hline $\mathrm{F}$ & $19.386 * * *$ & $39.259 * * *$ & $31.269 * * *$ & & \\
\hline
\end{tabular}

Figure 2 also shows the moderating effect of OC. It shows that if OC is low when JU is high, JS is decreased. However, if OC is high, higher JU leads to a slightly higher JS. This demonstrates that OC positively moderates the relationship between JU and JS.

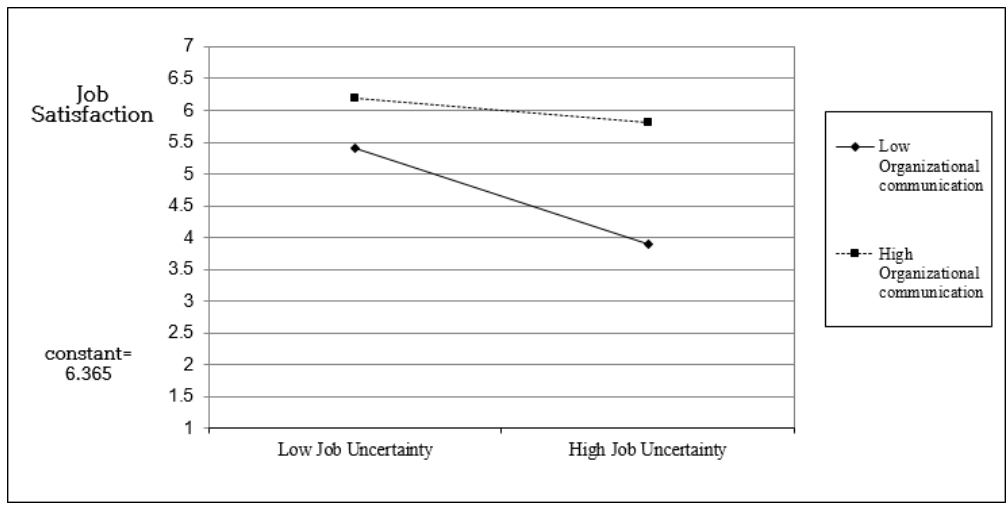

Figure 2. The moderating effect of OC

\section{Conclusion}

\subsection{Conclusion and Implications}

This study proved the correlation between JU and JS. The results of the study showed that JU had a significant negative correlation with JS. With more job uncertainty, member's JS will be lower. The results of this study demonstrated that high JU lowers the JS of members and negatively affects job performance, and thus reinforces the importance of JU. CL and OC have positive moderating effects on JU and JS. Leaders with CL in an organization are much more likely to present their vision clearly and succinctly, provide members with the necessary information, reassure their members, and make members feel less JU. OC alleviates the negative correlation between JU and JS. OC also showed a positive moderating effect on JU and JS. We postulated that SE would have a moderating effect between JU and JS, however according to the above results, SE showed no moderating effect.

We suggest that leaders should help members to develop a coherent future vision, to help them adjust more easily to changes. Further, organizations should share relevant information and ensure that members receive pertinent information about the organization they work for. Further, we suggest that organizations or leaders pay enough attention to, and provide sufficient support and help to their members.

\subsection{Limitations and Future Study}

In order to verify the moderating effects of CL, OC, and SE on the relationship between JU and JS, this study conducted an empirical analysis of employees in Korean companies. In future studies, it would be valuable to investigate a broader range of subjects. For example, it would be worth conducting an empirical analysis of workers in the IT industry (Jin \& Hahm, 2017) as well as workers in a wide range of other industries (Jin, Zheng \& Hahm, 2017). In addition, CL and OC showed moderating effects, but SE showed no moderating effect. There is also a need to study SE in more depth. Lastly, in future studies, measuring differences in organizational performance through JU will also be a valuable undertaking. 


\section{References}

Abdulkarim, B., Yacob, M. R., Abdullah, A. M., \& Radam, A. (2017). Households'preferences and Willingness to Pay for Watershed Services Attributes in North Selangor Peat Swamp Forest Malaysia. Asian Journal of Economic Modelling, 5(1), 98-109. https://doi.org/10.18488/journal.8/2017.5.1/8.1.98.109

Agle, B. R., Nagarajan, N. J., Sonnenfeld, J. A., \& Srinivasan, D. (2006). Does CEO charisma matter? An empirical analysis of the relationships among organizational performance, environmental uncertainty, and top management team perceptions of CEO charisma. Academy of Management Journal, 49(1), 161-174. https://doi.org/10.5465/amj.2006.20785800

Ali, A., \& Haseeb, M. (2019). Radio frequency identification (RFID) technology as a strategic tool towards higher performance of supply chain operations in textile and apparel industry of Malaysia. Uncertain Supply Chain Management, 7(2), 215-226. https://doi.org/10.5267/j.uscm.2018.10.004

Armenakis, A. A., \& Bedeian, A. G. (1999). Organizational change: A review of theory and research in the 1990s. Journal of Management, 25(1), 293-315. https://doi.org/10.1177/014920639902500303

Aspers, P. (2018). Forms of uncertainty reduction: Decision, valuation, and contest. Theory and Society, 47(2), 133-149. https://doi.org/10.1007/s11186-018-9311-0

Bandura, A. (1977). Self-efficacy: Toward a unifying theory of behavioral change. Psychological Review, 84(2), 191. https://doi.org/10.1037/0033-295X.84.2.191

Bandura, A. (1982). Self-efficacy mechanism in human agency. American Psychologist, 37(2), 122. https://doi.org/10.1037/0003-066X.37.2.122

Baron, R. M., \& Kenny, D. A. (1986). The moderator-mediator variable distinction in social psychological research: Conceptual, strategic, and statistical considerations. Journal of Personality and Social Psychology, 51(6), 1173. https://doi.org/10.1037/0022-3514.51.6.1173

Bass, B. M., \& Avolio, B. J. (1995). The Multifactor Leadership Questionnaire. MindGarden, Inc., Redwoodcity, CA. https://doi.org/10.1037/t03624-000

Bastien, D. T. (1987). Common patterns of behavior and communication in corporate mergers and acquisitions. Human Resource Management, 26(1), 17-33. https://doi.org/10.1002/hrm.3930260103

Bordia, P., Hobman, E., Jones, E., Gallois, C., \& Callan, V. J. (2004). Uncertainty during organizational change: Types, consequences, and management strategies. Journal of Business and Psychology, 18(4), 507-532. https://doi.org/10.1023/B:JOBU.0000028449.99127.f7

Chen, G., Gully, S. M., \& Eden, D. (2001). Validation of a new general self-efficacy scale. Organizational Research Methods, 4(1), 62-83. https://doi.org/10.1177/109442810141004

Dess, G. G., \& Beard, D. W. (1984). Dimension of organizational task environments. Administrative Science Quarterly, 29(1), 52-73. https://doi.org/10.2307/2393080

Dierker, L., Evia, J. R., Singer-Freeman, K., Woods, K., Zupkus, J., Arnholt, A., ... \& Rose, J. (2018). Project-Based Learning in Introductory Statistics: Comparing Course Experiences and Predicting Positive Outcomes for Students from Diverse Educational Settings. International Journal of Educational Technology and Learning, 3(2), 52-64. https://doi.org/10.20448/2003.32.52.64

Dolgopolova, I., Hye, Q. A. M., \& Stewart, I. T. (2014). Energy consumption and economic growth: evidence from non-OPEC oil producing states. Quality \& Quantity, 48(2), 887-898. https://doi.org/10.1007/s11135-012-9810-4

Dunst, C. J., Raab, M., Embler, D., \& Roberts, K. (2018). Developing Evidence-Informed Early Childhood Intervention E-Learning Lessons, Performance Checklists and Practice Guides. Journal of Education and e-Learning Research, 5(4), 242-248. https://doi.org/10.20448/journal.509.2018.54.242.248

Frahn, J., \& Brown, K. (2007). First steps: Linking change communication to change receptivity. Journal of Organizational Change Management, 20(3), 370-387. https://doi.org/10.1108/09534810710740191

Go, M. J., Go, H. N., Gwon, M. J., Kim, K. M., Kim, M. H., \& Kim, S. O. (2014). Interpersonal Relationship and Communication. Gomunsa Press, Seoul.

Hirst, J. D. (1981). A failure "without parallel": The school medical service and the London county council 1907-12. Medical History, 25(3), 281-300. https://doi.org/10.1017/S0025727300034591 
Hoppock, R. (1935). Job Satisfaction. Harper and Row, New York.

Jermsittiparsert, K. (2016). Culture of 'Elephant front legs-hind legs': A debate on the actuality of sexual politics in Thai society. The Social Sciences, 11(1), 20-28.

Jiang, L., \& Probst, T. M. (2014). Organizational communication: A buffer in times of job insecurity. Economic and Industrial Democracy, 35(3), 557-579. https://doi.org/10.1177/0143831X13489356

Jin, X., \& Hahm, S. W. (2017). The effect of authentic leadership on organizational commitment and organizational citizenship behavior in the IT industry: The moderating effects of self-efficacy. International Information Institute (Tokyo). Information, 20(6A), 3823-3834.

Jin, X., Zheng F. S., \& Hahm, S. W. (2017). The effects of compulsory organizational citizenship behavior on job burnout: the mediating effect of job stress. Asia-pacific Journal of Multimedia Services Convergent with Art, Humanities, and Sociology, 7(9), 559-568. https://doi.org/10.14257/AJMAHS.2017.09.59

Johnson, J. R., Bernhagen, M. J., Miller, V., \& Allen, M. (1996). The role of communication in managing reductions in work force. Journal of Applied Communication Research, 24, 139-164. https://doi.org/10.1080/00909889609365448

Kamau, L. M., Mwania, J., \& Njue, A. K. (2018). Technology resources for teaching secondary mathematics: lessons from early and late adopters of technology in Kenya. Asian Journal of Contemporary Education, 2(1), 43-52.

Lari, L. R. A., NYangweso, P. M., \& Rono, L. J. (2017). Determinants of Technical Inefficiency of Saccos in Kenya: A Net Operating Cash Flows Output Slack Analysis. Asian Journal of Economics and Empirical Research, 4(2), 49-60. https://doi.org/10.20448/journal.501.2017.42.49.60

Lewis, L. K. (2006). Employee perspectives on implementation communication as predictors of perceptions of success and resistance. Western Journal of Communication, 70, 23-46. https://doi.org/10.1080/10570310500506631

Locke, E. A. (1976). The Nature and Causes of Job Satisfaction. Handbook of industrial and organizational psychology, Rand McNally College Publishing Company.

Mossholder, K. W., Settoon, R. P., \& Henagan, S. C. (2005). A relational perspective on turnover: Examining structural, attitudinal, and behavioral predictors. Academy of Management Journal, 48(4), 607-618. https://doi.org/10.5465/amj.2005.17843941

Ng, V. (2018). Design/Make: An Alternative Practice to Collaborative Learning in Architecture. International Journal of Asian Social Science, 8(10), 828-840. https://doi.org/10.18488/journal.1.2018.810.828.840

Osuji, E. E., Ehirim, N. C., Rahji, M. A. Y., Awoyemi, T. T., Salman, K. K., Odii, M. A. C. A., ... Okwara, M. O. (2017). Farming Risks and Security Challenges in Vegetable Production in Orlu, Imo State. Asian Development Policy Review, 5(1), 37-42. https://doi.org/10.18488/journal.107/2017.5.1/107.1.37.42

Park, J. H., \& Jung, S. C. (2017). The influence of adaptability for uncertainty on turnover intention and the serial multiple mediating effect of role ambiguity and job satisfaction. Korean Journal of Industrial and Organizational Psychology, 30(2), 77-194. https://doi.org/10.24230/kjiop.v30i2.177-194

Park, S. C. (2018). The Fourth Industrial Revolution and implications for innovative cluster policies. AI and SOCIETY, 33(3), 433-445. https://doi.org/10.1007/s00146-017-0777-5

Paulsen, N., Callan, V. J., Grice, T. A., Rooney, D., Gallois, C., Jones, E., ... Bordia, P. (2005). Job uncertainty and personal control during downsizing: A comparison of survivors and victims. Human Relations, 58(4), 463-496. https://doi.org/10.1177/0018726705055033

Pfeffer, J. (1994). Competitive Advantage through People. Harvard Business School Press, Boston, MA. https://doi.org/10.2307/41165742

Price, J. L. (1997). Handbook of organizational measurement. International Journal of Manpower, 18(4/5/6), 305-558. https://doi.org/10.1108/01437729710182260

Rakab, M. B. (2018). The Frequency Effects of a Relatively Rarely Used Grammar Structure: The Case of Had Better. International Journal of English Language and Literature Studies, 7(4), 101-114. https://doi.org/10.18488/journal.23.2018.74.101.114

Ruan, B., Hsee, C. K., \& Lu, Z. Y. (2018). The teasing effect: An underappreciated benefit of creating and resolving an uncertainty. Journal of Marketing Research, 55(4), 556-570. https://doi.org/10.1509/jmr.15.0346 
Saad, S., Umer, I., \& Ahmed, F. (2018). An empirical evidence of over reaction hypothesis on karachi stock exchange (KSE). Asian Economic and Financial Review, 8(4), 449-465. https://doi.org/10.18488/journal.aefr.2018.84.449.465

Santos, J. R. A. (1999). Cronbach's alpha: A tool for assessing the reliability of scales. Journal of Extension, 37(2), $1-5$.

Smith, P. C. (1955). The prediction of individual differences in susceptibility to industrial monotony. Journal of Applied Psychology, 39, 322-329. https://doi.org/10.1037/h0043258

Umanath, N., \& Kim, K. (1992). Task-structure relationship of IS development subunit: A congruence perspective. Decision Sciences, 23(4), 819-838. https://doi.org/10.1111/j.1540-5915.1992.tb00421.x

Umrani, W. A., Mahmood, R., \& Ahmed, U. (2016). Unveiling the direct effect of corporate entrepreneurship's dimensions on the business performance: a case of big five banks in Pakistan. Studies in Business and Economics, 11(1), 181-195. https://doi.org/10.1515/sbe-2016-0015

Van de Ven, A. H., Delbecq, A. L., \& Koenig, R. (1976). Determinants of coordination models within organizations. American Sociological Review, 41, 322-338. https://doi.org/10.2307/2094477

Waldman, D. A., Ramirez, G. G., House, R. J., \& Puranam, P. (2001). Does leadership matter? CEO leadership attributes and profitability under conditions of perceived environmental uncertainty. Academy of Management Journal, 44(1), 134-143. https://doi.org/10.5465/3069341

Weber, M. (1947). The Theory of Social and Economic Organization (A. M. Henderson \& T. Parsons, Trans.). Oxford University Press, New York. 